\title{
骨盤内囊胞様の臨床像を呈した単形性上皮向性腸管 $\mathrm{T}$ 細胞リンパ腫の 1 例
}

\author{
東京都健康長寿医療センター外科 \\ 吉 本 恵 理 金澤伸郎渡部和玄 \\ 三井秀雄吉田孝司黑 岩 厚二郎
}

症例は82歳, 女性. 主訴は腹痛. 前医において腹痛の原因検索目的で腹部造影 CTを 施行し，骨盤内に限局した囊胞様腫瘤が指摘された，消化管穿孔による腹腔内膿瘍を疑 い，加療目的に当院へ転院搬送され，手術を施行した，手術所見では，消化管穿孔によ る骨盤内膿瘍形成ではなく，拡張した小腸が巨大な囊胞様腫瘤を形成していることが確 認された. 腫瘤は骨盤底に強固に癒着していたため可及的に小腸部分切除術を施行した. 術後検体の免疫染色では, CD3 (+), CD4 (-), CD5 (-), CD7 (+), CD8 (+), CD20(-), CD56(-), EBER in situ hybridization(-). また, 小〜中型の異型リン パ球様細胞が壁全層性に認められ, 粘膜では上皮向性で比較的単調に増殖・浸潤を示唆 する像がみられることから, MEITL (monomorphic epitheliotropic intestinal T-cell lymphoma）と診断した.

術後13日目に退院となり, 退院後は化学療法が施行されたが, 術後10力月目に化学療 法PD と評価され, best supportive careの方針となり, 術後12カ月で原病死した.

索引用語：MEITL, 腸症型 $\mathrm{T}$ 細胞リンパ腫, 囊胞様腫瘤

\section{はじめに}

腸症型 T細胞リンパ腫（enteropathy-associated T-cell lymphoma； EATL) は, celiac病に合併する ことが多いI 型と, 同疾患の関連が少ない II 型に分類 されていた ${ }^{1)}$.しかし, WHO分類改定第 4 版では, I 型が純粋なEATLと定義され，II 型は新たに MEITL (monomorphic epitheliotropic intestinal Tcell lymphoma）として再分類された23). 腸症型 $\mathrm{T}$ 細 胞リンパ腫は消化管原発悪性リンパ腫の中でも稀で, 狭窄や穿孔をきたす予後不良な疾患である。EATL・ MEITLは空腸や回腸に多く $70 \%$ 以上は空腸に起こ り，その他の消化管は稀である ${ }^{4)}$. 小腸腫瘍は，腸閉 塞や出血, 腫瘍の破裂やこれに伴う腸穿孔性による腹 膜炎を契機に診断されることが多く，腸症型 $\mathrm{T}$ 細胞 リンパ腫も同様である。近年ではカプセル内視鏡やダ ブルバルーン内視鏡の普及により術前に診断される症 例が増加しているものの, 検診で行われる検査ではな

2020年 7 月 3 日受付 2020 年11月 4 日採用

〈所属施設住所〉

₹173-0015 東京都板橋区栄町35-2
いため, 早期発見は未だ困難な状況である.

今回われわれは，消化管穿孔を伴わずに囊胞様腫瘤 を形成したMEITLの 1 例を経験したので, 若干の考 察を加え報告する。

\section{症例}

患者: 82歳, 女性.

主訴 : 腹痛.

既往歴：高血圧, 大動脈弁閉鎖不全症, 子宮筋腫核 出術.

家族歴：特になし.

現病歴：1力月前からの食思不振, 発熱, 軽度腹痛 を主訴に前医を受診した。CT所見で骨盤内膿瘍が疑 われたため, 加療目的に当院へ紹介受診され, 入院と なった.

入院時現症 : 体温 $37.6^{\circ} \mathrm{C}$, 血圧 $117 / 55 \mathrm{mmHg}$, 脈拍 91 分・整. 眼瞼結膜に貧血あり. 眼球結膜に黄疸なし. 頭頸部は特記事項なし. 胸部は呼吸音正常, 拡張期雑 音聴取. 腹部は下腹部正中に手術痕あり, 平坦・軟, 圧痛や反跳痛なし, 腸蠕動音正. 四肢浮腫あり。表在 リンパ節腫脹なし。

血液検査所見：白血球 $11,300 / \mu 1$ （好中球 $83.0 \%$, 

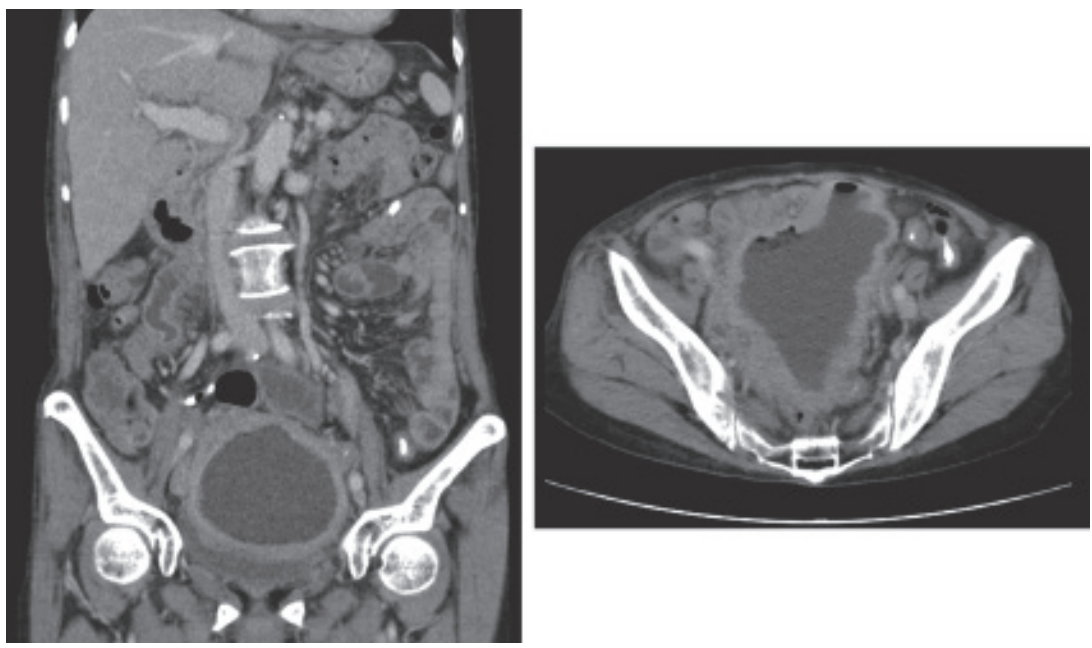

Fig. 1 腹部骨盤造影 CT 所見：骨盤腔内に $12 \mathrm{~cm}$ 大の腫瘤を認め, 内腔に液体とガスの貯 留を認めた.

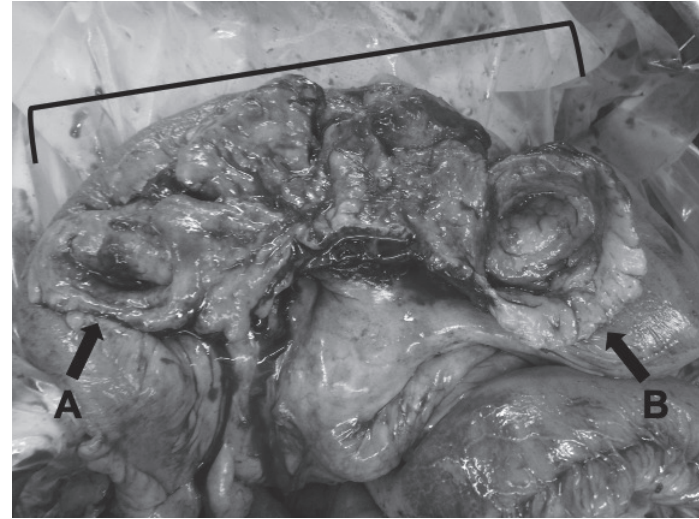

Fig. 2 手術所見：腫瘤は回腸末端より約 $60 \mathrm{~cm}$ 口側回腸 にあり，腫瘤壁が一部骨盤底に残ったため口側と肚門 側の腸管が開口している（腫瘤壁があった範囲：括弧 部分, 肛門側腸管断端：矢印 A, 口側腸管断端：矢印 B).

リンパ球 $10.0 \%$, 単球 $5.5 \%$, 好酸球 $0.0 \%$, 好塩基球 $0.0 \%), \mathrm{Hb} 7.1 \mathrm{~g} / \mathrm{dl}, \mathrm{CRP} 9.37 \mathrm{mg} / \mathrm{dl}$ で炎症反応高值 と貧血を認めた。腎機能, 肝胆道系酵素, 電解質に明 らかな異常は認めなかった。

腹部骨盤造影CT所見 : 骨盤腔内に最大径 $12 \mathrm{~cm}$, 内 腔に液体とガスの貯留を伴い，壁に造影効果のある囊 胞様腫瘤を認めた。口側腸管は腫瘤との連続性が疑わ れたが，肛門側腸管と内腔の連続性は画像上確認でき なかった. 腹水や腹腔内遊離ガスは認めなかった (Fig. 1).
臨床経過：前医において上・下部消化管内視鏡検査 が施行され，異常所見は認められなかった．当院受診 時, $37.6^{\circ} \mathrm{C}$ の微熱を認めたものの, 腹部症状はなかっ た. $\mathrm{Hb} 7.1 \mathrm{~g} / \mathrm{dl}$ と貧血を認めたため，入院後 MAP4 単位が輸血された。炎症反応高值に対して抗菌薬 （PIPC/TAZ）を投与したところ，炎症反応は速やか に改善した．腹部所見はそしかったものの，小腸穿孔 による膿瘍形成が否定できず手術を行った。

手術所見：腹腔内を検索すると腹水はなく，穿孔を 疑う所見は認めなかった。回腸が一部瘤状に拡張し骨 盤底と後腹膜に強固に癒着していた，瘤状に拡張した 回腸壁は厚い被膜様で，肚門側は狭窄しており，囊胞 様腫瘤を形成していた，強固な癒着のため，剥離操作 時に腫瘤の壁が一部破綻し内腔から暗緑色の腸液が漏 出した，腫瘤の組織は脆く，骨盤底への癒着により全 摘出することは不可能と判断し, 可及的に腫瘤の剥離 可能な部分とその前後正常腸管を切除し吻合を行っ

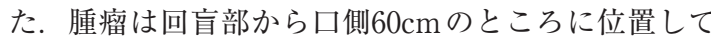
いた（Fig. 2).

摘出標本の肉眼的所見 : 腫瘤の口側の拡張部位に部 分的な壁肥厚を認め, 肛門側の内腔は軽度狭窄してい た。拡張部・狭窄部とも壁は柔軟であり，粘膜面は平 滑であった．割面は白色かつ均一で部分的に出血を伴 い，層構造は不明膫化していた。

病理組織学的検査所見 : 腸管の拡張部・狭窄部，お よび近傍の腸間膜組織において異型リンパ球様細胞の 


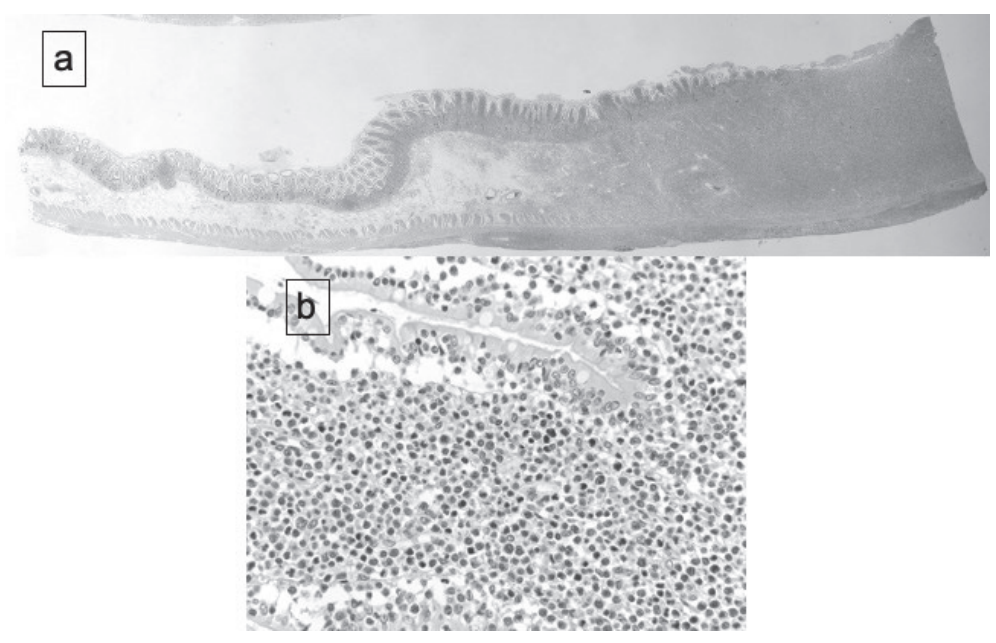

Fig. 3 病理組織学的所見（H.E.染色： a ; ルーペ像, b ; × ×40）：異型リンパ球 様細胞のびまん性増殖を認める. 小〜中型の比較的均一な異型細胞が壁全層性 に認められ，粘膜では上皮向性の浸潤を示唆する.
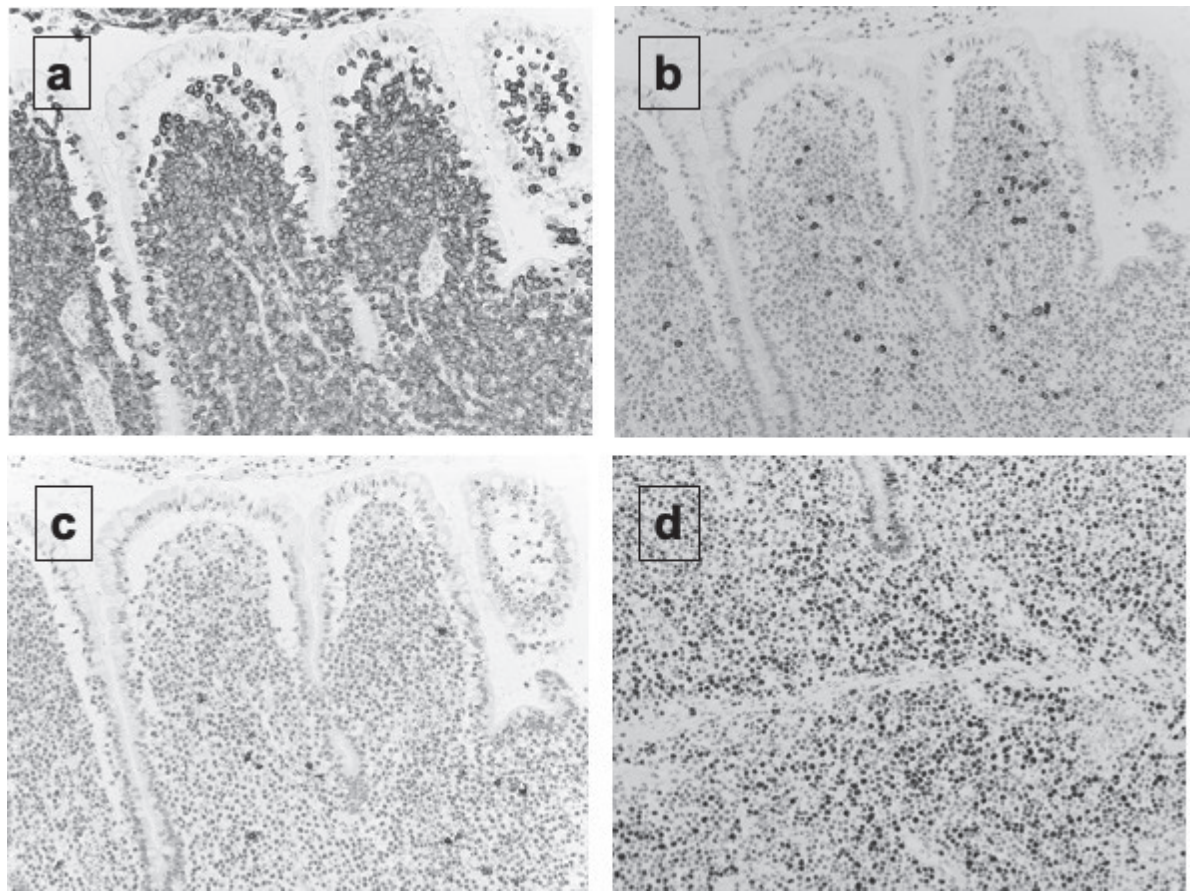

Fig. 4 免疫組織学的所見 $(\times 20)$ ： a : CD3 陽性, b : CD5 陰性, c : CD20陰性, d : MIB-1 index high (60-80\%).

びまん性増殖を認めた。腫瘤の拡張部位で異型細胞が 壁全層性に認められ，粘膜では上皮向性の浸潤を示唆 する像が認められた，異型細胞は小〜中型の比較的均
一な不整形核を有していた（Fig. 3)。免疫染色では， $\mathrm{CD} 3(+), \mathrm{CD} 4(-), \mathrm{CD} 5(-), \mathrm{CD} 7(+), \mathrm{CD} 8(+)$, $\mathrm{CD} 20(-), \operatorname{CD} 56(-), \operatorname{CD} 79 \mathrm{a}(-), \operatorname{TIA}-1(+)$, 
Table 1 小腸に発生した MEITL・EATL I 型の報告例（2009〜2019）

\begin{tabular}{|c|c|c|c|c|c|c|c|c|c|}
\hline 報告年 & 著者 & 年齢 & 性別 & 主訴 & 部位 & 穿孔 & 診断方法 & 治療方法 & 予後 \\
\hline 2010 & 深津 ${ }^{15)}$ & 75 & M & 血便 & 空腸 & なし & 手術 & 待機手術, 化学療法 & 18力月死亡 \\
\hline 2010 & Ikebe $^{16)}$ & 65 & $\mathrm{~F}$ & 腹痛, 下痢, 体重減少 & 十二指腸 & なし & 内視鏡 & 化学療法, ASCT & 移植後18力月生存 \\
\hline 2011 & 鈴木 ${ }^{17)}$ & 69 & M & タール便, 立ちくらみ & 回腸 & なし & 手術 & 待機手術, 化学療法 & 12 力月生存 \\
\hline 2011 & 山村18) & 61 & M & 腹痛 & 空腸 & あり & 手術 & $\begin{array}{c}\text { 緊急手術, 化学療法, } \\
\text { auto-PBSCT }\end{array}$ & 16力月生存 \\
\hline 2011 & 山田 ${ }^{19)}$ & 60 & M & 腹痛 & 空腸 & あり & 手術 & 緊急手術, 化学療法 & 4 力月死亡 \\
\hline 2012 & 西20) & 79 & M & 腹痛 & 空腸 & あり & 手術 & 緊急手術 & 62日死亡 \\
\hline 2012 & 野口 ${ }^{21)}$ & 50歳台 & $\mathrm{F}$ & 鯞下障害 & 回腸 & なし & 内視鏡 & $\begin{array}{c}\text { 緊急手術, 化学療法, } \\
\text { auto-PBSCT }\end{array}$ & 移植後 7 カ月死亡 \\
\hline 2013 & 平木22) & 60歳台 & M & 心窩部痛, 体重減少 & 胃, 空腸 & なし & 内視鏡 & 待機手術 & - \\
\hline 2013 & 菊間23) & 47 & $\mathrm{~F}$ & 下痢, 腹痛 & 回腸 & あり & 手術 & 緊急手術, 化学療法 & 36日死亡 \\
\hline 2014 & 河合24) & 53 & M & 全身倦㤐感, 腹痛 & 空腸 & あり & 手術 & 緊急手術 & 11日死亡 \\
\hline 2014 & 河合24) & 74 & M & 腹痛 & 空腸, 回腸 & あり & 手術 & 緊急手術, 化学療法 & 5 力月死亡 \\
\hline 2014 & 森本25) & 65 & M & 腹痛, 嘔吐 & 空腸 & なし & 内視鏡 & 化学療法, 緊急手術 & 11力月 \\
\hline 2014 & 福島 ${ }^{26)}$ & 60歳台 & M & 下痢 & 回腸 & なし & 内視鏡 & 化学療法 & 13カ月死亡 \\
\hline 2014 & 河毛27) & 71 & M & 腹痛 & 空腸 & あり & 手術 & 緊急手術, 化学療法 & 3 力月死亡 \\
\hline 2014 & 河毛27) & 84 & M & 下腹部痛, 嘔吐 & 空腸 & あり & 手術 & 緊急手術, 化学療法 & 10力月生存 \\
\hline 2014 & 嵭村28) & 59 & M & 発熱, 貧血 & 回腸 & あり & 手術 & $\begin{array}{c}\text { 緊急手術, 化学療法, } \\
\text { auto-PBSCT }\end{array}$ & 276日死亡 \\
\hline 2015 & 西田29) & 75 & M & 下腹部違和感, 体重減少, 便秘 & 空腸 & なし & 手術 & 緊急手術, 化学療法 & 20カ月 \\
\hline 2015 & 野村30) & 69 & M & 左側腹痛 & 空腸 & なし & 内視鏡 & 待機手術, 化学療法 & 3 力月死亡 \\
\hline 2017 & 小西31) & 83 & $\mathrm{~F}$ & 腹痛, 吐血 & 十二指腸～上部空腸 & なし & 内視鏡 & なし & 59日死亡 \\
\hline 2017 & 武田 ${ }^{32)}$ & 74 & $\mathrm{~F}$ & 黒色便 & 空腸 & なし & 内視鏡 & 待機手術, 化学療法 & 6 力月死亡 \\
\hline 2017 & 樋口 ${ }^{33)}$ & 67 & M & 腹痛 & 空腸 & あり & 手術 & 緊急手術 & 14 力月生存 \\
\hline 2018 & 石橋8) & 70 & M & 嘔気, 腹部膨満 & 十二指腸下行脚 & なし & 内視鏡 & 化学療法 & 5 力月死亡 \\
\hline 2018 & 真田 ${ }^{34)}$ & 78 & M & 腹痛 & 空腸, 回腸 & 瘻孔 & 手術 & 緊急手術, 化学療法 & 250日死亡 \\
\hline 2018 & 福富35) & 52 & M & 腹痛 & 空腸 & あり & 手術 & $\begin{array}{c}\text { 緊急手術, 化学療法, } \\
\text { auto-PBSCT }\end{array}$ & 11力月生存 \\
\hline 2018 & 住居36) & 73 & M & 体重減少, 下血. & 空腸 & なし & 手術 & $\begin{array}{c}\text { 待機手術, 化学療法, } \\
\text { auto-PBSCT }\end{array}$ & 21カ月死亡 \\
\hline 2018 & 熊川 ${ }^{37)}$ & 54 & M & 体重減少, 心窩部痛, 食思不振 & 空腸 & なし & 内視鏡 & 待機手術, 化学療法 & - \\
\hline 2018 & 中村 ${ }^{38)}$ & 50歳台 & $\mathrm{F}$ & なし & 十二指腸, 下行結腸 & あり & 内視鏡 & 化学療法, 緊急手術 & 6 力月死亡 \\
\hline 2019 & 河野39) & 60歳台 & M & 体重減少, 腹部膨満 & 十二指腸下行脚 & なし & 内視鏡 & 化学療法, auto-PBSCT & 8 力月死亡 \\
\hline 2019 & 河野39) & 60歳台 & $\mathrm{F}$ & 腹痛, 発熱 & 上部空腸 & あり & 手術 & 緊急手術, 化学療法 & 6 力月死亡 \\
\hline 2019 & 柳川40) & 85 & M & 発熱, 腹痛 & 空腸 & なし & 手術 & 待機手術 & 8 力月生存 \\
\hline 2019 & 柳川 ${ }^{40)}$ & 88 & M & なし & 空腸 & なし & 手術 & 待機手術 & 4 力月生存 \\
\hline 2020 & 本症例 & 82 & $\mathrm{~F}$ & 腹痛 & 回腸 & なし & 手術 & 待機手術, 化学療法 & 12力月死亡 \\
\hline
\end{tabular}

ASCT : 自家造血幹細胞移植, auto-PBSCT : 自家末梢血幹細胞移植, 一 : 記载なし.

Granzyme $\mathrm{B}(+)$, PAX-5(-), EBER in situ hybridization $(-)$, MIB-1 index high (60 80\%) で あった（Fig. 4). 以上の所見から MEITLと診断され た.

術後経過 : 術後経過は良好で, 術後13日目で退院し た，術後27日目に再入院し化学療法を開始した．本症 例は高齢および心機能障害を考慮され，CVP（cyclophosphamide, vincristine sulfate, prednisone) 療法 1 コース, 続いてDeVIC (Dexamethasone, Etoposide, Ifosfamide, Carboplatin) 療法 3 コース, intermediate dose MTX療法が2コース施行された. 化学療法開始 6 力月目にFDG-PET検查でPD となっ たため, ロミデプシン療法へ変更され 1 コース施行し たが，腫瘍増大による両側水腎症を合併し全身状態不
良となり，術後10力月目で best supportive careの方 針で療養型病院へ転院され, 術後12力月で原病死した.

\section{考察}

腸症型 $\mathrm{T}$ 細胞リンパ腫（enteropathy-associated T-cell lymphoma；EATL) のほとんどは欧米でみら れ, celiac病の多い北欧で頻度が高い。Celiac病の 頻度の高い欧州では悪性リンパ腫の $9.1 \%$ を占め, 北 欧でも $5.8 \%$ を占めるが, アジアでは $1.9 \%$ と頻度が低 いとされている5)。本邦での腸症型 T細胞リンパ腫の 発生頻度も，全悪性リンパ腫の $0.27 \%, \mathrm{NK} / \mathrm{T}$ 細胞腫 瘍の約 $1.4 \%$ と低く，稀な疾患である ${ }^{6)}$.わが国をはじ めとするアジア諸国では MEITLがほとんどを占め, celiac病を基盤とするEATLは非常に稀である. Takeshita らがまとめた本邦24例の腸症型 T 細胞リン 
パ腫の病理組織学的所見でも, MEITLが $83 \%$ と多い 傾向にあると報告している7 .

EATLとMEITLはいずれも臨床的に急速に進行す る経過をたどることが多い，年齢の中央值は約60歳で 高齢者に発症することが多く，また占居部位は小腸に 多くみられ，70\%以上は空腸に起こり，その他の消化 管に起こることは稀とされている4).一方, 石橋らは, MEITLの占拠部位は食道から直腸までの全消化管に 及ぶが，空腸が $39 \%$ ，回腸が $23 \%$ と小腸に好発すると 報告している8 ${ }^{8}$.

EATL と MEITLに共通する像としては, CD3 (+), $\mathrm{CD} 4(-), \mathrm{CD} 5(-), \mathrm{CD} 7(+)$ であり, 腸上皮内 $\mathrm{T}$ 細胞由来と考えられている。リンパ腫細胞がしばしば 腸管粘膜上皮へ浸潤して, リンパ上皮様病変に類似し た像やPautrier微小膿瘍を呈する。

$\operatorname{EATL} の$ 多くはCD8 (-), CD56(-) となり, 中型 から大型の腫瘍細胞が混在し, びまん性増殖を示す. 背景には組織球, 好中球, 好酸球, 形質細胞などの炎 症細胞浸潤を伴うことが多い.

一方, MEITLの多くはCD8 (+), CD56 (+) となり, 比較的小型から中型の腫瘍細胞が単調な増殖を示し, 壊死は少なく，炎症細胞浸潤は目立たない．

本症例は, CD56(-)であることがやや非典型的と 考えられたが，比較的小型から中型の腫瘍細胞が単調 に増殖し，炎症細胞浸潤の乏しい組織像であることか ら MEITLと診断した（Fig. 3, 4).

悪性リンパ腫の病変の広がりは治療選択, 予後予測 に大きく影響するため, 病期を正確に把握することが 重要である. 消化管原発悪性リンパ腫の病期分類は, Ann Arbor 分類9) に加えてLugano 病期分類 (1994) ${ }^{10)}$ が用いられており, Kikumuraら ${ }^{11)}$ は, MEITL 26例 の解析結果において臨床病期 I ・ II 期は IIE 期・IV 期 と比べて優位に予後が良好であったと報告している. 本症例はLugano 病期分類 IIE [後腹膜］であった.

Dawson ら ${ }^{12)}$ は，消化管原発悪性リンパ腫の診断基 準として，11消化管病変が主体で転移は所属リンパ節 のみである，(2)表在リンパ節の腫大がない，(3)胸部単 純 X線検査で縦隔リンパ節の腫大がない，(4)末梢血の 血球検査で白血病化がない, (5)肝臓・脾臟に腫瘍を認 めない, との 5 項目を提唱しており, 本症例は以上の 5 項目すべてを満たしていた．

外科治療の選択, 予後を評価するにはNaqvi 分類 ${ }^{13)}$ が有用である. stage I・IIであれば病巣部を含む可及 的広範囲切除とリンパ節郭清, stage III・IVであれば
姑息的手術が推奨されている ${ }^{14)}$. 本症例はNaqvi分類 Stage IIIであり，姑息的手術の適応であった.

今回われわれは，医中誌で「小腸」「MEITL」「単 形性上皮向性腸管 T細胞リンパ腫」「EATL II」「腸症 型T細胞リンパ腫」をキーワードとし，2009年から 2019年で検索したところ, 会議録を除き詳細な経過記 載があった症例と本症例を含めた 32 症例を認め, 文献 的内容から臨床データの集計を行い検討した（Table 1) ${ }^{8) 15) \sim 40)}$.

年齢の中央值は70.5 $(47-88)$ 歳. 男女比は $24: 8$ で男性の方が多く報告されていた，主訴は腹痛が20例 (62.5\%) と最も多く, 下痢, 腹部膨満, 下血, 吐気・ 嘔吐, 体重減少, 発熱など他症状を有しているものが 多かった。一方, 主訴がなく, 検查で偶然発見された 症例が 2 例 (6.2\%) あった. 占居部位（重複あり）は, 空腸が22例 (68.7\%) と最も多く, 次いで回腸 8 例 (25 $\%)$, 十二指腸 5 例 $(15.6 \%)$, 空腸 - 回腸 2 例 $(6.2 \%)$ であった。

悪性リンパ腫は全身病であり, 治療法としては化学 療法が主体である．EATLと MEITLは未だ標準治療 は確立されて抢らず, aggressive lymphomaとしての 化学療法が選択されるが, 治療抵抗性である. 自家造 血幹細胞移植や自家末梢血幹細胞移植を併用した大量 化学療法の治療が有効であったという報告もあ る(16)1939) が, 一般的にCHOP (cyclophosphamide, doxorubicin, vincristine, prednisone) 療法が選択さ れることが多く, しかし満足のいく結果は得られてい ない.

腸症型 $\mathrm{T}$ 細胞リンパ腫の予後は, 1 年生存率 $38.7 \%$, 5 年生存率 $19.7 \%$ と極めて不良であったと, Galeらが 報告している ${ }^{41)}$.

今回の検討では, 手術と化学療法を施行したものが 21 例 $(65.6 \%)$ と最も多く, 手術のみの症例 6 例 (18.7 $\%)$, 化学療法のみの症例が 4 例 $(12.5 \%)$, 未治療症 例が 1 例（3.1\%）であった。全症例の生存期間中央 值は 8 力月 (11日-21力月) であり, 手術と化学療法 の併用は8.75力月 (36日-21力月), 手術のみは 4 カ月 (11日-14力月), 化学療法施行例では10.5力月（ 5 力 月-18力月）であった. 化学療法のみは症例数が少な いものの, 生存期間を延長する可能性があることが示 唆された。手術と化学療法を併用した症例で, 緊急手 術と化学療法を施行した群14例と, 待機手術と化学療 法を施行した群 7 例で生存期間中央值を検討してみる と, 前者が7.65力月（36日-20カ月）で, 後者が11カ 
月（3 カ月 -21 力月）であった. 待機手術と化学療法 群の方が，生存期間が延長される結果となった。

消化管穿孔症例は13例（40.6\%）あり，その全症例 で緊急手術が施行されていた。非穿孔症例は瘦孔症例 の 1 例 ${ }^{34)}$ を含めると 19 例 $(59.3 \%)$ であり, 治療法に ついては, 化学療法症例は 4 例 $(21 \%)$, 化学療法と 手術の併用 11 例 $(57.8 \%)$ ，手術のみ 3 例 $(15.7 \%)$, 未治療症例が 1 例 $(5.2 \%)$ であった. 消化管穿孔の 有無で生存期間中央值を比べると, 穿孔群は 6 力月 (11 日-16力月), 非穿孔群は8.3力月（59日-21力月）であ った．消化管穿孔をきたした症例は重篤な経過を辿る ことが多いため，予後不良であるとされている24).

今回の検討では, 消化管穿孔症例は予後不良であり, 待機手術と化学療法を併用した方が, 生存期間が延長 される結果となった.

われわれは, 術前 CT 画像でガスを含んだ厚い壁を 持つ骨盤内囊胞様腫瘤が指摘されたことから, 消化管 穿孔による膿瘍形成を疑い手術の方針としたが，小腸 内視鏡検査を施行できたなら，化学療法をはじめに行 う選択肢もあったと考えられる。

MEITLは非常に稀な症例であり予後不良であるた め, 今後も早期の診断・治療による症例蓄積が重要で あると思われる.

\section{結語}

今回われわれは，消化管穿孔を伴わず骨盤内囊胞様 の臨床像を呈したMEITLの 1 例を経験した. 本邦に おけるMEITLの報告は少なく，治療方針は未だ確立 していない. 穿孔に至らず発見できた場合には予後が 改善する可能性もあるため, 本疾患の画像的特徴を念 頭に置き, 早期に診断し，集学的治療を行うことが重 要であると考えられた。

利益相反：なし

\section{文献}

1) Issacson PG, Chott A, Ott G, et al : Enteropathyassociation $\mathrm{T}$-cell lymphoma. Swerdlow $\mathrm{SH}$, Campo E, Harris NL, et al (eds.), WHO Classification of Tumors of Haematopoietic and Lymphoid Tissues, 4th ed., IARC, Lyon, 2008, p289291

2) Bhagat G, Jaffe ES, Chott A, et al : Enteropathyassociated T-cell lymphoma. Swerdlow SH, Campo E, Harris NL, et al (eds.), WHO Classification of Tumors of Haematopoietic and Lym- phoid Tissues, revised 4th ed., IARC, Lyon, 2017, p372- 377

3) Jaffe ES, Chott A, Ott G, et al : Monomorphic epitheliotropic intestinal $\mathrm{T}$-cell lymphoma. Swerdlow SH, Campo E, Harris NL, et al (eds.), WHO Classification of Tumors of Haematopoietic and Lymphoid Tissues, revised 4th ed., IARC, Lyon, 2017, p377-378

4）藤井将義, 佐藤康晴, 吉野 正：成熟 $\mathrm{T}$ および $\mathrm{NK}$ 細胞腫瘍。腸 $\mathrm{T}$ 細胞リンパ腫。中村栄男, 大 島孝一, 竹内賢吾他, リンパ腫アトラス, 第 5 版, 文光堂, 東京, 2018, p219-223

5) Delabie J, Holte H, Vose JM, et al : Enteropathyassociated T-cell lymphoma : clinical and histological findings from the International Peripheral T-Cell Lymphoma Project. Blood $2011 ; 118$ : $148-155$

6) Lymphoma Study Group of Japanese Pathologists : The World Health Organization classification of malignant lymphomas in Japan : Incidence of recently recognized entities. Pathol Int $2000 ; 50: 696-702$

7) Takeshita M, Nakamura S, Kikuma K, et al : Pathological and immunohistological findings and genetic aberrations of intestinal enteropathy-associated T cell lymphoma in japan. Histopathology $2011 ; 58: 395-407$

8）石橋英樹，二村 聡，萱嶋善行他：十二指腸下行 脚に狭窄を来したmonomorphic epitheliotropic intestinal T-cell lymphomaの 1 例. 胃と腸 2018; $53: 1684-1692$

9) Cheson BD, Fisher RI, Barrington SF, et al : Recommendations for initial evaluation, staging, and response assessment of Hodgikin and nonHodgkin lymphoma : the Lugano classification. J Clin Oncol $2014 ; 32: 3059-3068$

10) Rohatiner A, d'Amore F, Coiffier B, et al : Report on a workshop convened to discuss the pathological and staging classifications of gastrointestinal tract lymphoma. Ann Oncol 1994 ; 5 : $397-400$

11) Kikumura K, Yamada K, Nakamura S, et al : Detailed clinicopathological characteristics and possible lymphomagenesis of type II intestinal en- 
teropathy-associated T-cell lymphoma in Japan. Hum Pathol $2014 ; 45$ : 1276- 1284

12) Dawson IMP, Corners JS, Morson BC : Primary malignant lymphoid tumor of the intestinal tract. Report of 37 cases with a study of factor influences of prognosis. Br J Surg 1961 ; 49 : 80 $-89$

13) Naqvi MS, Burrows L, Kark AE : Lymphoma of the gastrointestinal tract. Prognostic guides based on 162 cases. Ann Surg 1977 ; 170 : 221 231

14）三浦一郎, 森 茂久：腸のリンパ腫. 血腫瘍 $2004 ; 49: 696-700$

15）深津和弘, 若杉 聡, 平田信人他：血便を契機に 診断された小腸EATLの 1 例. Prog Dig Endosc $2010 ; 76: 74-75$

16) Ikebe T, Miyazaki Y, Abe Y, et al : Successful treatment of refractory enteropathy-assciated T-cell lymphoma using high-dose chemotherapy and autologous stem cell transplatation. Intern Med 2010 ; 49 : $2157-2161$

17）鈴木潮人, 田尻亮輔, 大井章史：孤立性腸管症関 連 T細胞リンパ腫の 1 例。診断病理 $2011 ； 28$ ： $21-24$

18）山村和生, 石榑 清, 石田直子他：穿孔性腹膜炎 で発症し, 集学的治療により寛解が得られた腸管 症型 T細胞リンパ腫の 1 例。 日臨外会誌 2011 ； $72: 812-817$

19）山田大作，小関萬里，冨永春海：HTLV-1キャリ アーに穿孔性腹膜炎で発症した腸管型 $\mathrm{T}$ 細胞性 悪性リンパ腫の 1 例. 日臨外会誌 $2011 ; 72: 97$ $-102$

20）西 智史, 森 周介, 西田保則：小腸穿孔による 腹膜炎で生じた II 型腸管症型 $\mathrm{T}$ 細胞リンパ腫. 日 消外会誌 $2012 ; 45: 1059-1065$

21）野口寛子, 中西勝也, 計良淑子他：噁下障害を契 機に食道生検によって診断に至った腸症型 $\mathrm{T}$ 細 胞リンパ腫の 1 例. 診断病理 $2012 ; 29: 76-79$

22）平木 翼, 東美智代, 北島信一他：小腸と胃に病 変を形成した enteropathy-associated T-cell lymphomaの 1 例. 診断病理 $2013 ; 30: 253-257$

23）菊間幹太, 山田 梢, 二村 聡他：広範な粘膜内 増殖を示した腸管症関連 $\mathrm{T}$ 細胞リンパ腫 $\mathrm{II}$ 型の 1

例. 診断病理 $2013 ; 30: 108-111$
24）河合典子, 岩井和浩, 佐藤暢人他：消化管穿孔を きたした腸管症型 $\mathrm{T}$ 細胞性リンパ腫の 2 例。日臨 外会誌 $2014 ; 75: 2783-2788$

25）森本浩史, 森田高行, 梄崎 肇他：2 回の切除を 施行した腸管症型 $\mathrm{T}$ 細胞リンパ腫の 1 例。日臨外 会誌 $2014 ; 75: 1882-1886$

26）福島政司, 河南智治晴, 細谷和也他 : ダブルバル ーン内視鏡で経過観察しえたenteropathy-associated T-cell lymphomaの 1 例. 胃と腸 2014； $49: 1326-1332$

27）河毛利顕, 田原 浩, 前田佳之他：空腸穿孔をき たした II 型腸管症関連 T細胞リンパ腫の 2 例. 日 臨外会誌 $2014 ; 75: 1308-1315$

28）㟝村千恵, 河本真大, 吳 幸枝他 : 小腸穿孔をき たした II 型腸管症関連 T細胞リンパ腫の 1 例。 日 臨外会誌 $2014 ; 75: 2229-2233$

29）西田浩子, 遠藤 聖, 波多野まみ他：孤立性中枢 神経再発をきたしたII 型腸管症関連 T 細胞リンパ 腫. 臨血 $2015 ; 56: 692-698$

30）野村尚弘, 富家由美，柴田有宏他：十二指腸と小 腸に多発した腸管症型 $\mathrm{T}$ 細胞リンパ腫の 1 例。日 臨外会誌 $2015 ; 76: 774-779$

31）小西直樹, 岩本淳一, 淺岡 純他：吐血を契機に 診断された十二指腸・近位空腸 $\mathrm{T}$ 細胞リンパ腫の 1 例. Prog Dig Endosc 2017; 90 : 104-105

32）武田輝之, 宗 祐人, 森光洋介他：消化管出血を 契機に診断しえた腸管症関連 $\mathrm{T}$ 細胞リンパ腫 II 型 の 1 例. Gastroenterol Endosc 2017; $59: 2614$ $-2620$

33）樋口 格, 中村隆俊, 佐藤武郎他：小腸穿孔をき たしたII型腸管症関連 T細胞リンパ腫の 1 例。 日 腹部救急医会誌 $2017 ; 37: 739-742$

34）真田祥太朗, 福岡伴樹, 冨永奈沙他：小腸と㾇孔 を形成した腸管症型 $\mathrm{T}$ 細胞リンパ腫の 1 例. 日消 外会誌 $2018 ; 51: 640-648$

35）福冨章悟, 藤崎正寛, 真田咲子他：消化管穿孔を 契機に診断されたII 型腸管症型 T 細胞リンパ腫の 1 切除例. 臨と研 $2018 ; 95: 899-901$

36）住居優一, 山本和彦, 大村泰之他：自家末梢血幹 細胞移植を施行した高齢の早期再発腸管症関連 $\mathrm{T}$ 細胞リンパ腫．臨血２018；59：889-894

37）熊川友子, 山岡 稔, 都築義和：ダブルバルーン 内視鏡で診断した腸管症関連 T細胞性リンパ腫 の 1 例. Prog Dig Endosc 2018; $92: 124-125$ 
38）中村公彦, 中山盛隆, 田口 淳他：化学療法中に 小腸穿孔をきたした単形性上皮向性腸管 $\mathrm{T}$ 細胞 リンパ腫の 1 例. 静岡赤十字病研報 2018；38： $1-7$

39）河野信一, 鳥巣剛弘, 小林広幸 : Monomorphic epitheliotropic T-cell lymphomaの 2 例. 胃と腸 $2019 ; 54: 543-552$
40）柳川直樹，齋藤明見，緒方真也他：単形性上皮向 性腸管 T細胞リンパ腫の 2 例. 外科 $2019 ; 81$ ： $1373-1376$

41) Gale J, Simmonds PD, Mead GM, et al : Enteropathy-type intestinal T-cell lymphoma: clinical features and treatment of 31 patients in a single center. J Clin Oncol $2000 ; 18: 795-803$

\title{
A CASE OF MONOMORPHIC EPITHELIOTROPIC INTESTINAL T-CELL LYMPHOMA WITH A CLINICAL PRESENTATION SIMILAR TO THAT OF AN INTRAPELVIC CYST
}

\author{
Eri YOSHIMOTO, Nobuo KANAZAWA, Kazuharu WATANABE, Hideo MITSUI, \\ Takashi YOSHIDA and Koujirou KUROIWA \\ Department of Surgery, Tokyo Metropolitan Geriatric Medical Center
}

An 82-year-old woman presented with abdominal pain. Abdominal contrast-enhanced computed tomography (CT) done at another hospital to investigate the cause showed a cystic mass localized within the pelvic cavity. An intraperitoneal abscess due to gastrointestinal perforation was suspected, and she was transferred to our hospital for treatment. During surgery, rather than an intrapelvic abscess due to gastrointestinal perforation, it was found that the dilated small intestine had formed a massive cystic mass. Because this mass adhered tightly to the pelvic floor, as much of the small intestine as possible was resected. Immunostaining of the postoperative samples was CD3(+), CD4(-), CD5 $(-), \operatorname{CD} 7(+), \operatorname{CD} 8(+)$, CD20(-), CD56(-), and EBER in situ hybridization (-). Small to medium-sized atypical lymphoid cells were present throughout the entire thickness of the wall, and they showed comparatively monomorphic epitheliotropic proliferation and invasion in the mucosa, leading to a diagnosis of monomorphic epitheliotropic intestinal T-cell lymphoma (MEITL). The patient was discharged on postoperative Day 13 and underwent chemotherapy after discharge. However, she developed progressive disease 10 months postoperatively and was switched to best supportive care. She died of the original condition 12 months postoperatively.

Key words : MEITL, enteropathy-associated T-cell lymphoma, cystic tumor 